\title{
COMPARATIVE STUDY INTERLEAVED INVERTER WITH BOOST STAGE AND ACTIVE DECOUPLING CIRCUIT
}

\author{
A. P. FESENKO*, O. O. MATUSHKIN, O. O. HUSEV
}

Department of Biomedical Radioelectronic Apparatus and Systems, Chernihiv National University of Technology, Chernihiv, UKRAINE

*email: gudrunas_ch@gmail.com

\begin{abstract}
Google little box challenge competition attracted high interest to problem of size and cost reducing of the converter as a part of photovoltaic power supply system. One of the ways is find a proper topology of the inverter. Selected for analyze solution is interleaved inverter. The assumption is made that the energy in passive component is in proportion through the inductor current. The reducing of the energy in passive component is expected for the selected solution. Selected schema consists of three main functional blocks. The first one is parallel boost converter with interleaving of switch control signal. The second part is an active decoupling circuit. Its main role is reducing of power pulsation on input of the inverter. And the third part is single phase interleaved inverter with output LCL filter.For estimation of energy reducing conventional solution also was considered. As conventional solution boost full bridge inverter with active decoupling circuit was selected. It consists of the same functional parts without interleaving switch control signals. The main goal of this paper was the definition and presentation the efficiency of boost interleaved inverter with active decoupling circuit in field of size and value optimization for inductors. Two models are made for simulation of both schemas. As simulation environment PSCAD version 4.5 is used. Both schemas have the same parameters: input voltage $150 \mathrm{~V}$, output power $1 \mathrm{~kW}$, switching frequency $50 \mathrm{kHz}$.
\end{abstract}

Key words: parallel boost converter; interleaved inverter; active power decoupling circuit; power inverter.

\section{ПОРІВНЯЛЬНИЙ АНАЛІЗ ІНВЕРТОРА НА ОСНОВІ ПАРАЛЕЛЬНОЇ СТРУКТУРИ ЧЕРГУВАННЯ ФАЗ 3 ПІДСИЛЮВАЛЬНИМ КАСКАДОМ І АКТИВНИМ ЛАНЦЮЖКОМ ЗГЛАДЖУВАННЯ ПУЛЬСАЦЙ ВХІДНОЇ ПОТУЖНОСТІ}

\author{
А. П. ФЕСЕНКО*, О. О. МАТЮШКІН, О. О. ГУСЕВ
}

кафедра біомедичних радіоелектронних апаратів та систем, Чернігівський національний технологічний університет, Чернігів, УКРАЇНА

\begin{abstract}
АНОТАЦІЯ Дана стаття представляс результати порівняння моделей інвертора з фазовим перекриттям сигналів керування, перетворювачем, щзо підвищує та ланцюжком розв'язки активної потужності з мостовим інвертором 3 перетворювачем, щзо підвищує. Порівняння наведено для відносних величин енергій в пасивних компонентах. Розглянута нова топологія ставить за мету зменшення енергій в пасивних компонентах. Ця система розрахована на вихідну потужність 1 кBm та широкий діапазон вхідної напруги. Наведено результати розрахунку компонентів та результати моделювання.

Ключові слова: паралельний перетворювач, що підвищує; інвертор з фазовим перекриттям сигналів керування; ланцюжок розв 'язки активної потужності; інвертор.
\end{abstract}

\section{Introduction}

With the awareness of mankind of his responsibility for environmental degradation decrease the part of renewable energy sources. Important kind of that's sources are solar energy systems. And one of the types of these systems is solar power supply system for housekeeping. Structure of this system is shown in Fig. 1.

The photovoltaic panel provides conversion energy of solar light into electrical energy. Charge controller control process of storage energy. The battery provides storage energy. Inverter provides converting energy of direct current into energy of grid alternating current.

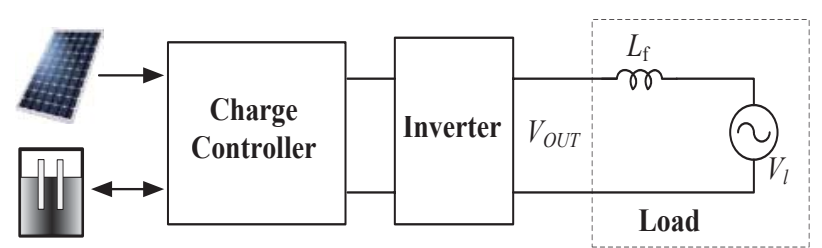

Fig. 1 - System structure

The one of the actual problem is a design of small, cheap and high-power inverter for such system.

The Google Little Box Challenge (GLBC) demonstrated extremely high interest to the topic of high-power density inverters for Photovoltaic (PV) application. It demonstrated that extremely high 
power density of a power electronics converter is achievable 0 .

One of the GLBC project outcomes is a concept of extremely high power density converter. The finalists demonstrated similar approach. It includes one full-bridge interleaved inverter, active decoupling circuit and output EMI-filter.

The modern level of technics puts forward new requirements and opportunities for designers. New active components deprived some disadvantages and have some interesting features. In general, active components are becoming smaller, cheaper, more high-frequency, less losses. At the same time, passive component remains at the same level. Systems with many switches are promising. On the other hand, modern level of microcontrollers, DSP, FPGA provides implementation of the very complicated control systems with small expanse.

The interesting method to increase output voltage and reduce ripple is using boost converter with two parallel inductors [3]. The advantages of such schema are small input current ripple and reduced conduction losses.

High voltage $\mathrm{SiC}$ MOSFET switches can ensure fast switching and acceptable losses [4]. Proposed solution assume high voltage $(3,3 \mathrm{kV})$ for two phases interleaved inverter with zero voltage switching.

Usually, discussed three-phase interleaved grid connected invertors [5]. Such schema consists of three parallel full-bridge three-phase inverter and LCL output filter. Control system includes three DSP, each one for his phase. For grid connected systems was proposed single stage boost interleaved inverter [6].

Discontinuous space vector modulation (SVM) is interesting and perspective control methods not only for three-phase systems [7]. Grate achievement for three-phase systems is generation a zero-sequence excitation to the system.

Usually, different active power decoupling circuit used in the rectifiers [8-10]. In these schemas decoupling circuit located between rectifier and load. His function is reducing pulsation in the output voltage. There many different type of decupling cells, such as boost type, buck type, buck-boost type, Hbridge with inductor or capacitor, parallel and series, [11-12]. Some systems have two active power decoupling cells. First is on the ac side, secondis onthe dc side [13]. Active decoupling using in quasi$\mathrm{Z}$ sources with hysteresis current control is shown here [14]. Decoupling cell include RLC passive component and two switches.

Similar approach was proposed for multilevel quasi-Z inverter [15]. Inverter consists of two fullbridges. Each one has additional circuit from two switches and LC passive component. That cell was included parallel to the bridge and the load.
The review and comparisons of different types of the power pulsation buffer (PPB) in dc-ac converter systems was represented in [12]. Five types of PPB were compared: notch filter, buck and boost, flying capacitor, stacked capacitor approach. Applying the buck circuit was recognized as the most effective solution for such systems.

\section{The goal of the work}

The main goal of this paper is comparison of boost interleaved inverter with active decoupling circuit and boost full bridge inverter in the field of passive component energy in terms of efficiency and size of passive components.

\section{Selected solution}

The boost interleaved inverter with active power decoupling ws selected for simulation. It consists of three main functional parts. Each one will be detail reviewed further in this paper.

The new approach is compared with conventional solution - boost full-bridge inverter with active decoupling circuit. Both schemas presented in Fig. 2. Where proposed solution is highlighted with grey color and conventional represented with black color. Both variants include three similar blocks.

\section{A. Boost converter}

Selected solution contains boost converter due to input voltage reregulation. That's why system needs circuit for increased voltage. Converter with two parallel inductors is chosen for simulation.

The work of this circuit based on energy storage in inductor and extraction this energy to the load. Switches control system algorithm provides stabilization of the output voltage. Because input source is photovoltaic panel, input voltage may change in wide range and input voltage of inverter must be stabilize.

In the proposed schema the inductors $L_{1}$ and $L_{2}$ are equal $L_{1}=L_{2}$. The input current [16] can be calculated by the input voltage and power (1). Where input and output power are equal.

$$
I_{L}=\frac{P_{B O U T}}{V_{I N}},
$$

The indictor current may be expressed by (2):

$$
\Delta I_{L}=\int_{0}^{T_{S} \gamma} \frac{d i_{L}}{d t} d t=\int_{0}^{T_{S \gamma} \gamma} \frac{V_{I N}}{L} d t=\frac{V_{I N}}{L} \cdot T_{S} \gamma
$$

where $T_{S}$ is the switching period. 


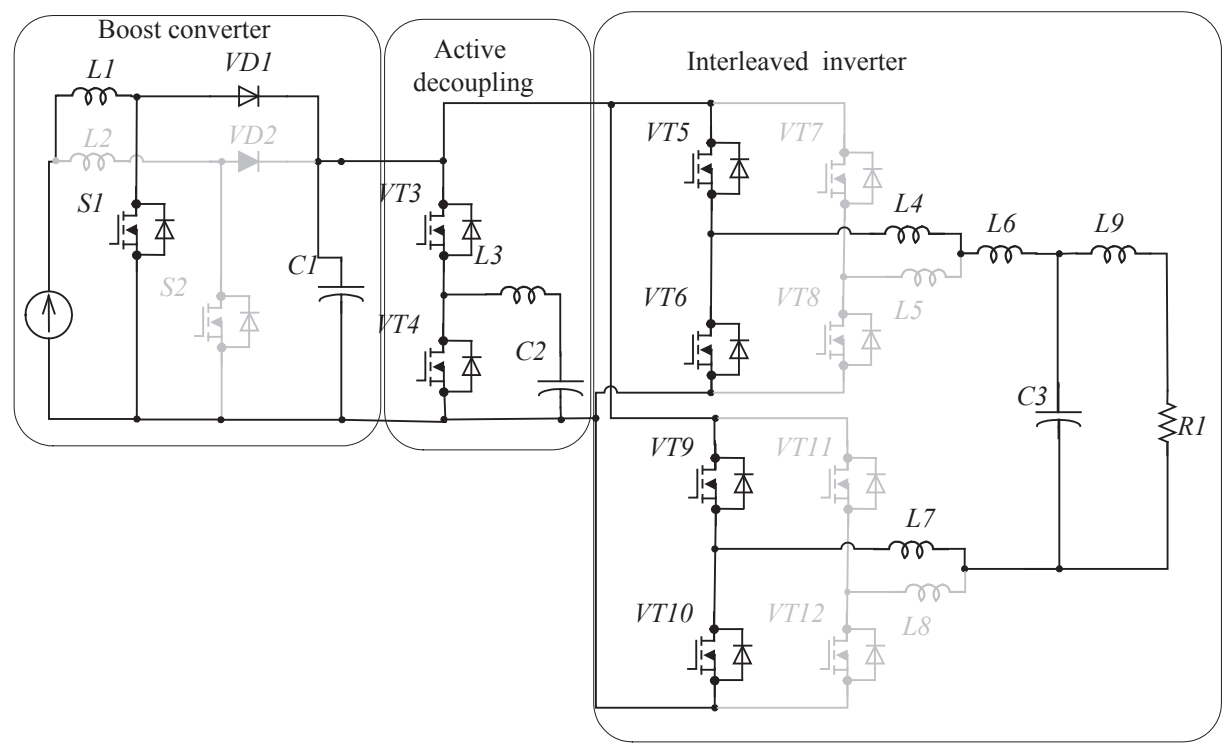

Fig. 2 - Considered solution

The inductance of the dc-dc boost converter can be expressed through the current ripple factor $K_{L}$ :

$$
K_{L}=\frac{\Delta I_{L}}{I_{L}}=\frac{V_{I N}^{2}}{P_{B O U T} \cdot L} \cdot T_{S} \gamma,
$$

One unit of the inductance corresponds to the condition $V_{I N}=\frac{V_{P L}}{2}$, where $f_{S}$ is switching frequency.

$$
L=\frac{V_{P L}^{2}}{4 \cdot P_{B O U T} \cdot f_{S} \cdot K_{L}},
$$

The inductance is expressed as:

$$
L_{1}=L \cdot \frac{8 \cdot V_{I N}{ }^{2} \cdot\left(V_{P L}-V_{I N}\right)}{V_{P L}{ }^{3}},
$$

Voltages on the capacitors are described as:

$$
V_{C 1}=\frac{V_{D C}}{2}=\frac{V_{P L}}{2},
$$

The capacitor voltage ripples are:

$$
\Delta V_{C}=\frac{1}{C} \int_{0}^{T_{S} \gamma} i_{C}(t) d t=\frac{P_{B O U T}}{V_{D C} \cdot C} \cdot T_{S} \gamma,
$$

The capacitances of the dc-dc boost converter can be expressed through the dc voltage ripple factor $K_{C}$ :

$$
K_{C}=\frac{\Delta V_{C}}{V_{C}}=\frac{2 \cdot P_{B O U T}}{V_{D C} \cdot V_{D C} \cdot C \cdot f_{S}} \cdot \gamma
$$

One unit of the capacitor corresponds to the condition $V_{I N}=\frac{V_{P L}}{2}$ :

$$
C=\frac{2 \cdot P_{B O U T}}{V_{P L}^{2} \cdot f_{S} \cdot K_{C}},
$$

In this case capacitances will be according to the following equation:

$$
C_{1}=C \cdot \frac{V_{P L}-V_{I N}}{V_{P L}}
$$

B. Active power decoupling

Active power decoupling circuit performs function of pulsation buffering. The work principles based on storage and extraction energy in passive LC-circuit for compensation voltage pulsation on the input of inverter.

\section{Interleaved inverter}

The inverter provides converting energy of dc into energy of grid accurrent. Selected for consideration solution consist of interleaved inverter.

The main fiche of this type of inverter is using two bridge schemas for single-phase system Fig. 5. The first bridge (switches 5-8) and second bridge (switches 9-12) is working similarly, with inverse control signals.

Switches 5, 6 and switches 7, 8 work with phaseshift control signals. Value of this shift is half period of switching signal. It allows decreasing current across each one switch and inductor. The load current summed up into load from two components. 
This type of inverter is selected because it has some significant advantages for photovoltaic systems.

The main advantages are: lower switch and inductor current, smaller and cheaper passive component and switch, lower loses in passive component. The main disadvantages are: difficult control system, more switches, higher loses in switches.

Calculation of output LCL-filter elements were done using voltage distortion approach [16].

\section{Simulation results}

Input voltages for selected and conventional schemes are $150 \mathrm{~V}$, output voltage $220 \mathrm{~V}, 50 \mathrm{~Hz}$. Switching frequency $50 \mathrm{kHz}$. Output power $1 \mathrm{~kW}$.

Input current and inductor L1 current presents in Fig. 3. As it can be seen, the current pulsation is lower than $2.9 \%$. That's meets the requirements. Inductor L1 current similar to inductor L2, because switches 1 and 2 works with inverse control signals.

The simulation is done in PSCad version 4.5. The passive component values for both schemas are presented in Table 1. The simulation is done for the active load.

Table 1 - Passive components value

\begin{tabular}{|c|c|c|}
\hline \multirow{2}{*}{ Component } & \multicolumn{2}{|c|}{ Value } \\
\cline { 2 - 3 } & Interleaved & Full-Bridge \\
\hline C1 & \multicolumn{2}{|c|}{$1.6 \mu \mathrm{F}$} \\
\hline C2 & \multicolumn{2}{|c|}{$150 \mu \mathrm{F}$} \\
\hline C3 & $0.66 \mu \mathrm{F}$ & $10.0 \mu \mathrm{F}$ \\
\hline L1, L2 & $1.54 \mathrm{mH}$ & $3.24 \mathrm{mH}$ \\
\hline L3 & \multicolumn{2}{|c|}{$5 \mathrm{mH}$} \\
\hline L4, L5, L7, L8 & $1.2 \mu \mathrm{H}$ & $2.4 \mathrm{mH}$ \\
\hline L6 & \multicolumn{2}{|c|}{$66 \mu \mathrm{H}$} \\
\hline L9 & \multicolumn{2}{|c|}{$20 \mu \mathrm{H}$} \\
\hline
\end{tabular}

The values of passive components are taken with a margin. In future works it will be optimized.

DC-link voltage is taken from $\mathrm{C} 1$. Voltage pulsation is less than $8.9 \%$. That's meets the requirements, that the pulsation must be less than $20 \%$ in Fig. 3.

Input, dc-link and output voltages are shown in Fig. 4. Total harmonic distortion of the output voltage less than $3,6 \%$. That's meets the requirements, that the pulsation must be less than $5 \%$.

One of the features of interleaved inverter is output inductors current that is shown in Fig. 5. As shown on diagram, inductors current has some shift. And load current is the sum of these two components, each on is lower than the sum of them.

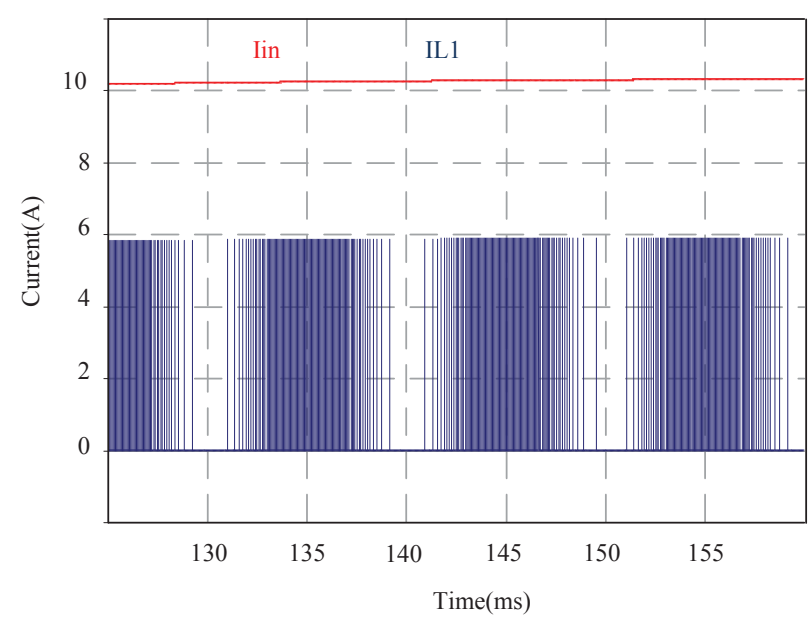

Fig. 3 - Input and inductor L1 current

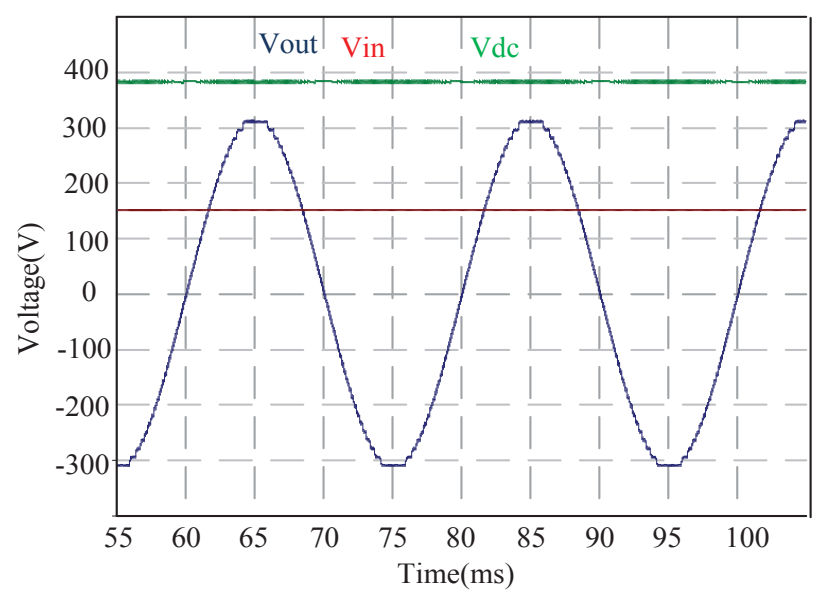

Fig. 4-dc-link, input and output voltage.

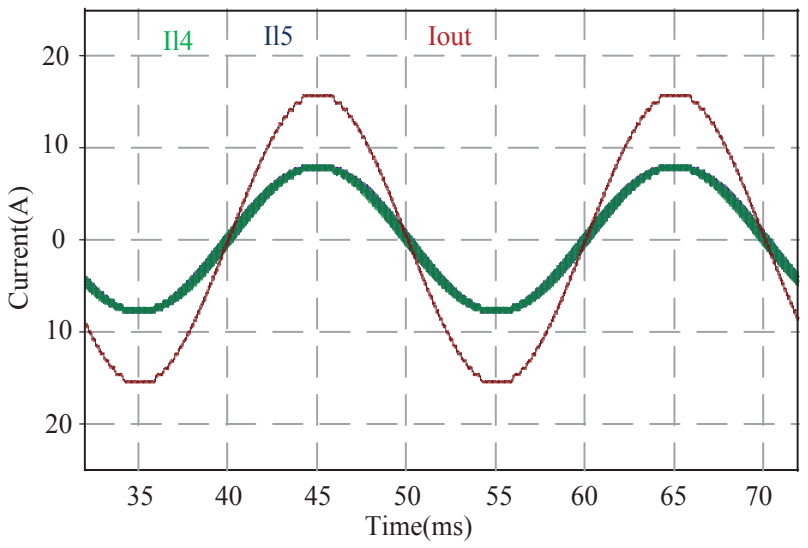

Fig. 5 -Inductor L4, L5, output current

For comparison of energy in passive components, conduction loses; voltage drop on active components diagram is shown in Fig. 6. This case includes simulation results for both solutions under the same initial condition. 


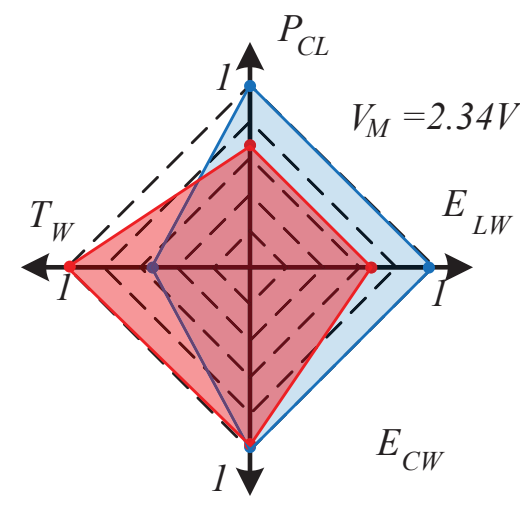

- Boost Interleaved inverter

- Full-bridge inverter

Fig. 6-Energy comparison diagram

Represented results improved initial assumptions. New approach reduced energy in inductors almost on $30 \%$.

\section{Conclusions}

Interleaved inverter is acceptable solution for solar power supply systems. It has some significant advantages, such as lower one switch current, smaller and cheaper passive component. His disadvantages partially compensated with modern state of element base.

Initial assumptions are verified by simulation results. Boost interleaved inverter provide energy decreasing in inductors by almost $30 \%$. This leads to the size decreasing of inductors and device at all. Also an advantage of such solution is the cost decreasing, because inductor for smaller current needs less copper and is cheaper.

\section{Bibliography}

1. Bortis, D. $\eta \rho$-Pareto optimization and comparative evaluation of inverter concepts considered for the GOOGLE Little Box Challenge / D. Bortis, D. Neumayr, J. W. Kolar // in proc of IEEE 17th Workshop on Control and Modeling for Power Electronics (COMPEL) - 2016. - P. 1- 5. doi:10.1109/COMPEL.2016.7556767.

2. Morsy, A. Comparison of Active Power Decoupling Methods for High-Power-Density Single-Phase Inverters Using Wide-Band gap FETs for Google Little Box Challenge / A. Morsy, P. Enjeti //in proc. IEEE Journal of Emerging and Selected Topics in Power Electronics. - 2016. - Vol. 4, Issue 3. - P. 790-798. doi:10.1109/JESTPE.2016.2573262.

3. Lee, Po-Wa. Steady-State Analysis of an Interleaved Boost Converter with Coupled Inductors / Po-Wa Lee, Yim-Shu Lee, David Cheng, Liu Xiu-Cheng // proc. IEEE Transactions On Industrial Electronics. - 2000. - Vol. 47, 4. - P. 787-795. - doi:10.1109/41.857959.
4. Rixin, Lai. A high efficiency two-phase interleaved inverter for wide range output waveform generation / Rixin Lai, Lei Wang, Juan Sabate // in proc. Energy Conversion Congress and Exposition (ECCE). - 2012. - P. 235-239. doi:10.1109/ECCE.2012.6342204.

5. Abusara, M. Design and control of a grid-connected interleaved inverter / Mohammad A. Abusara, Suleiman M. Sharkh // in proc. IEEE Transactions On Power Electronics. - 2013. - Vol. 28, 2. - P.748-764. doi:10.1002/9780470824054.ch7.

6. Omar, Abdel-Rahim. Buck-Boost Interleaved Inverter for Grid Connected Photovoltaic System/ Omar Abdel-Rahim, Mohamed Orabi, Mahrous E. Ahmed // in proc. IEEE International Conference on Power and Energy (PECon2010). - 2010. - P.63-68. -doi: 10.1109/PECON.2010.5697558.

7. Xing, Kun. Interleaved PWM with Discontinuous Space-Vector Modulation / Kun Xing, Fred C. Lee, Dusan Borojevic, Zhihong Ye, Sudip Mazumder // in proc. IEEE TRANSACTIONS ON POWER ELECTRONICS. - 1999. Vol. 14, 5. - P. 906-917. - doi:10.1109/63.788496.

8. Shimizu, Toshihisa. DC Ripple Current Reduction on a Single-PhasePWM Voltage-Source Rectifier / Toshihisa Shimizu, Yasuhiro Jin, Gunji Kimura // in proc. IEEE Transactions On Industry Applications. - 2000. - Vol. 36, 5. - P. 1419-1429. - doi:10.1109/IAS.1999.801600.

9. Wang, Ruxi. Study of Energy Storage Capacitor Reduction for Single Phase PWM Rectifier / Ruxi Wang, Fred Wang, Rixin Lai, Puqi Ning, Rolando Burgos, Dushan Boroyevich // in proc. Applied Power Electronics Conference and Exposition. - 2009. - P.764-771. doi:10.1109/41.857959.

10. Chao, Kuo-Hen. New Control Methods for Single Phase PWM Regenerative Rectifier with Power DecouplingFunction / Kuo-Hen Chao, Po-Tai Cheng, Toshihisa Shimizu // proc. Power Electronics and Drive Systems. - 2009. - $\quad$ P. 1091-1096. doi:10.1109/PEDS.2009.5385686.

11. Sun, Yao. Review of Active Power Decoupling Topologies in Single-Phase Systems / Yao Sun, Yonglu Liu, Mei Su, Wenjing Xiong, Jian Yang // proc. IEEE Transactions On Power Electronics. - 2016. - Vol. 31, 7. - P. 4778-4794. doi:10.1109/TPEL.2015.2477882.

12. Neumayr, D. Ultra-Compact Power Pulsation Buffer for Single-Phase DC/AC Converter Systems / D. Neumayr, D. Bortis, J. W. Kolar // proc. IEEE 8th International Power Electronics and Motion Control Conference (IPEMC-ECCE Asia). - $2016 . \quad$ - $\quad$ P. $1-10 . \quad-$ doi:10.1109/IPEMC.2016.7512730.

13. Qin, Zian. Benchmark of AC and DC Active Power Decoupling Circuits for Second Order Harmonic Mitigation in kW-scale Single-Phase Inverters / Zian Qin, Yi Tang, Poh Chiang Loh, Frede Blaabjerg // proc. IEEE Journal of Emerging and Selected Topics in Power Electronics. 2015. - Vol. 4, 1. - P.431-435. doi:10.1109/ECCE.2015.7310013.

14. Siddhartha, A. Capacitance Reduction in a Single Phase Quasi Z-source Inverter using a Hysteresis CurrentControlled Active Power Filter / A. Siddhartha, Najath A. Azeez, Sheldon S. Williamson // proc. Industrial Electronics (ISIE), 2016 IEEE 25th International Symposium. - 2016. - P. 805-810. doi:10.1109/ISIE.2016.7744993.

15. Yushan, Liu. An Active Power Decoupling Quasi-Z-Source Cascaded Multilevel Inverter / Yushan Liu, Baoming Ge, Haitham Abu-Rub // proc. Industrial Electronics Society, 
IECON. - $2016 \quad-\quad$ P. 6453-6458.

doi:10.1109/IECON.2016.7794120.

16. Husev, Oleksandr. Voltage Distortion Approach for Output Filter Design for Off-Grid and Grid-Connected PWM Inverters / OleksandrHusev, Andrii Chub, Enrique Romero-Cadaval, Carlos Roncero-Clemente, Dmitri Vinnikov // proc. Journal of Power Electronics. - 2015. Vol. 15, 1. - P. 278-287. - doi:10.6113/JPE.2015.15.1.278.

\section{Bibliography (transliterated)}

1. Bortis, D. Neumayr, D., Kolar, J. W. $\eta \rho$-Pareto optimization and comparative evaluation of inverter concepts considered for the GOOGLE Little Box Challenge.in proc of IEEE 17th Workshop on Control and Modeling for Power Electronics (COMPEL), 2016, 1-5, doi:10.1109/COMPEL.2016.7556767.

2. Morsy, A. Enjeti, P. Comparison of Active Power Decoupling Methods for High-Power-Density SinglePhase Inverters Using Wide-Band gap FETs for Google Little Box Challenge. in proc. IEEE Journal of Emerging and Selected Topics in Power Electronics, 2016, 4, 3, 790-798, doi:10.1109/ JESTPE.2016.2573262.

3. Lee, Po-Wa., Lee, Yim-Shu, Cheng, David K. W., Liu, Xiu-Cheng. Steady-State Analysis of an Interleaved Boost Converter with Coupled Inductors // proc. IEEE Transactions On Industrial Electronics, 2000, Vol. 47, 4, 787-795, doi:10.1109/41.857959.

4. Lai, Rixin. A high efficiency two-phase interleaved inverter for wide range output waveform generation Rixin Lai, Lei Wang, Juan Sabate // in proc. Energy Conversion Congress and Exposition (ECCE), 2012, 235-239, doi:10.1109/ECCE.2012.6342204.

5. Abusara, Mohammad. Design and control of a gridconnected interleaved inverter/ Mohammad A. Abusara and Suleiman M. Sharkh//in proc. IEEE TRANSACTIONS ON POWER ELECTRONICS, 2013, 28, 2, 748-764, doi:10.1002/9780470824054.ch7.

6. Omar, Abdel-Rahim, Orabi, Mohamed, Mahrous, E. Ahmed. Buck-Boost Interleaved Inverter for Grid Connected Photovoltaic System // in proc. IEEE International Conference on Power and Energy (PECon2010), 2010, 63-68, doi:10.1109/PECON.2010.5697558.

7. Xing, Kun, Lee, Fred C., Borojevic, Dusan, Zhihong, Ye, Mazumder, Sudip. Interleaved PWM with Discontinuous

Space-Vector Modulation // in proc. IEEE Transactions On Power Electronics, 1999, 14, 5, 906-917, doi:10.1109/63.788496
8. Shimizu, Toshihisa, Jin, Yasuhiro, Kimura, Gunji. DC Ripple Current Reduction on a Single-Phase PWM Voltage-Source Rectifier // in proc. IEEE Transactions On Industry Applications, 2000, 36, 5, 1419-1429, doi:10.1109/IAS.1999.801600.

9. Wang, Ruxi, Wang, Fred, Lai, Rixin, Ning, Puqi, Burgos, Rolando, Boroyevich, Dushan. Study of Energy Storage Capacitor Reduction for Single Phase PWM Rectifier // in proc. Applied Power Electronics Conference and Exposition, 2009, 764-771, doi:10.1109/41.857959.

10. Chao, Kuo-Hen, Cheng, Po-Tai, Shimizu, Toshihisa. New Control Methods for Single Phase PWM Regenerative Rectifier with Power Decoupling Function // proc. Power Electronics and Drive Systems, 2009, 1091-1096, doi:10.1109/PEDS.2009.5385686.

11. Yao, Sun, Yonglu, Liu, Mei, Su, Wenjing, Xiong, Jian, Yang. Review of Active Power Decoupling Topologiesin Single-Phase Systems // proc. IEEE Transactions On Power Electronics, 2016, 7, 47784794, doi:10.1109/TPEL.2015.2477882.

12. Neumayr, D. Bortis, D., Kolar, J. W. Ultra-Compact Power Pulsation Buffer for Single-Phase DC/AC Converter Systems // proc. IEEE 8th International Power Electronics and Motion Control Conference (IPEMC-ECCE Asia), 2016, 1-10, doi:10.1109/IPEMC.2016.7512730.

13. Qin, Zianm, Tang, Yi, Loh, Poh Chiang, Blaabjerg, Frede. Benchmark of AC and DC Active Power Decoupling Circuits for Second Order Harmonic Mitigation in $\mathrm{kW}$-scale Single-Phase Inverters // proc. IEEE Journal of Emerging and Selected Topics in Power Electronics, 2015, 4, 1, 431-435, doi:10.1109/ECCE.2015.7310013.

14. Siddhartha, A. Azeez, Najath A., Williamson, Sheldon S. Capacitance Reduction in a Single Phase Quasi Z-source Inverter using a Hysteresis Current Controlled Active Power Filter // proc. Industrial Electronics (ISIE), 2016 IEEE 25th International Symposium, 2016, 805-810, doi:10.1109/ISIE.2016.7744993.

15. Liu, Yushan, Baoming, Ge, Haitham, Abu-Rub. An Active Power Decoupling Quasi-Z-Source Cascaded Multilevel Inverter // proc. Industrial Electronics Society, IECON, 2016, 6453-6458, doi:10.1109/IECON.2016.7794120.

16. Husev, Oleksandr, Chub, Andrii, Romero-Cadaval, Enrique, Roncero-Clemente, Carlos, Vinnikov, Dmitri. Voltage Distortion Approach for Output Filter Design for Off-Grid and Grid-Connected PWM Inverters // proc. Journal of Power Electronics, 2015, 15, 1, 278-287, doi:10.6113/JPE.2015.15.1.278.

About authors (відомості про авторів)

Artem Fesenko - PhD student, assistant of Department Biomedical Radioelectronic Apparatus and Systems, Chernihiv National University of Technology, Chernihiv, Ukraine; e-mail: gudrunas.ch@mail.ua.

Фесенко Артем Петрович - Чернігівський національний технологічний університет, аспірант кафедри біомедичних радіоелектронних апаратів та систем; м. Чернігів, Україна; e-mail: gudrunas.ch@mail.ua.

Olexandr Matiushkin - master in field "Electronic systems", Chernihiv National University of Technology; Chernihiv, Ukraine; e-mail: matushkin1994@gmail.com.

Матюшкін Олександр Олександрович - магістр 3 електроніки, Чернігівський національний технологічний університет; Чернігів, Україна; е-mail: matushkin1994@gmail.com. 
Oleksandr Husev - PhD in Technical Sciences, Associate Professor, Associate Professor of Department of Biomedical Radioelectronic Apparatus and Systems, Chernihiv National University of Technology; Chernihiv, Ukraine; e-mail: oleksandr.husev@gmail.com.

Гусев Олександр Олександрович - кандидат технічних наук, доцент, доцент кафедри біомедичних радіоелектронних апаратів та систем, Чернігівський національний технологічний університет; м. Чернігів, Україна; е-таil: oleksandr.husev@gmail.com.

Please cite this article as:

Fesenko, A. P., Matushkin, O. O., Husev, O. O. Comparative study interleaved inverter with boost stage and active decoupling circuit. Bulletin of NTU "KhPI". Series: New solutions in modern technologies. - Kharkiv: NTU "KhPI", 2018,26 (1302), 1, 68-74, doi:10.20998/2413-4295.2018.26.10.

Будь ласка, посилайтесь на иъю статтю наступним чином:

Фесенко, А. П. Порівняльний аналіз інвертора на основі паралельної структури чергування фаз з підсилювальним каскадом і активним ланцюжком згладжування пульсацій вхідної потужності / А. П. Фесенко, О. О. Матюшкін, О. О. Гусев // Вісник НТУ «ХПІ», Серія: Нові рішення в сучасних технологіях. - Харків: НТУ «ХПІ». - 2018. - № 26 (1302). - T. 1. - C. 68-74. - doi:10.20998/2413-4295.2018.26.10.

Пожалуйста, ссылайтесь на эту статью следующим образом:

Фесенко, А. П. Сравнительный анализ инвертора на основе параллельной структуры чередования фаз с усилительным каскадом и активной цепочкой сглаживания пульсаций входной мощности / А. П. Фесенко, О. О. Матюшкин, О. О. Гусев // Вестник НТУ «ХПИ», Серия: Новые решения в современных технологиях. - Харьков: НТУ «ХПИ». - 2018. - № 26 (1302). - Т. 1. - С. 68-74. - doi:10.20998/2413-4295.2018.26.10.

АННОТАЦИЯ Данная статья представляет результаты сравнения моделей инвертора с фазовым перекрытием сигналов управления, повышающим преобразователем и цепочкой развязки активной мощности с мостовым инвертором с повышающим преобразователем. Сравнение приведено для относительных величин энергий в пассивных компонентах. Рассмотреная новая топология ставит иелью уменьшения энергий в пассивных компонентах. Эта система рассчитана на выходную мощность $1 \mathrm{\kappa Bm}$ и более широкий диапазон входного напряжения. Приведены результаты расчета компонентов и результаты моделирования.

Ключевые слова: параллельный повышающий преобразователь; инвертор с фазовым перекрытием сигналов управления; цепочка развязки активной мощности; инвертор. 